\title{
Toxic waste dumping, water contamination, and people's disablement in semi-arid rural México: local water pond issues for the fair siting of a landfill
}

\author{
F. J. Rangel \\ El Colegio de San Luis, A. C., San Luis Potosí, México
}

\begin{abstract}
In 1993, when Metalclad Corporation, an American landfill management firm, bought a closed toxic waste dump at La Pedrera - in the semi-arid rural region of Guadalcazár, México - from the Mexican Company Coterin, the issue of toxic waste disposal entered the consciousness of this developing country. But, by 1997, when Metalclad initiated arbitration proceedings over Mexico's refusal to permit Metalclad to re-open and operate the site because of the amount of toxic waste in it and the threat to the local water supply, the consequences to the place and to the community were displaced by concerns about international trade and foreign investment. As part of an ethnographic case study describing how people in El Huizache - the nearest locality to the site - have been affected, this paper recovers the forgotten history of a contaminated community, documenting the plight of a village under stress from climate, toxic waste dumping, water contamination, and a complex institutional context. Behind the national and international public concerns, the North American Free Trade Agreement implications, the professional controversies, and the political realities the Metalclad case has revealed, there might be a sample of the social consequences a poor environmental and cultural understanding of a body pond watershed can have. The findings of this paper suggest that when it comes to fair rules for siting a landfill, a semi-arid rural water pond in México is not just "a nice body of water smaller than a lake", but a real community storage vessel that serves to regulate and store the excess volume of water drained in the rainy season, in order to use excess in times of drought, when runoff is low.
\end{abstract}

Keywords: toxic waste, water contamination, climate, pond watershed, México. 


\section{Introduction}

During its clandestine construction in 1991, the toxic waste dump sited at the arroyo La Pedrera, in semi-arid rural Guadalcazár, México, was surrounded by austere berms that served as paths of deviation and as protective walls. Their purpose was to prevent surface runoff of rain-water from running down and coming into contact with the site and carrying pollutants to other bodies of water in the Matehuala-El Huizache Valley.

However, in August 2005 (almost 15 years after its closure), while outlining a Risk Perception Shadow [1] to define the geo-cultural area in which populations near the dump felt threatened by the site, the initial findings of this study revealed that in May 1991, when the dump was still operating "normally" by Mexican company Coterin, a storm swept into the pond of El Huizache (the closest village to the site) the contents of several 200-liter drums and plastic bags filled with industrial waste.

At the time, that pollution incident and the villager's alarm caused the closure of the dump, and eventually stopped its transformation into a secure landfill by U.S. Company Metalclad, generating a debate between experts, technicians, lawyers, and other specialists from government and industry, about key issues such as security and risks to the environment and the affected population.

Still, neither the actors directly involved in the case, nor the case studies carried out, addressed the locals' concerns over safety and fairness, so the inhabitants of El Huizache suddenly found themselves in a complex institutional context made up of the various local, state, and federal agencies having jurisdiction over their contaminating incident. This may have been an unfamiliar life context for most of them, one for which they lacked experience, and one in which their lives were essentially captured by agencies on which they became dependent for clarification and assistance, forcing them to rely on others to understand what had happened to their water reservoir [2].

A detailed ethnographic case study designed to address that information gap has revealed that during the controversial siting dilemma none of the site's assessments seriously considered the locals' risk perceptions nor the dramatic changes the pollution of its main water supply (primarily intended for livestock and domestic use) brought to the community.

It is conceivable that based on the widespread belief of ground water being the most vulnerable natural resource to hazardous waste pollution - and on the difficulties in dealing with ground water contamination as it occurs underground, out of sight, so the pollution sources are not easily observed, nor are their effects seen until damage, which is often irreversible, has been done [3] - most institutional (governmental and scientific) site assessments focused on the effects of the waste dump to ground water, ignoring the importance and significance some surface water dynamics may have in semi-arid contexts (dynamics such as precipitation, runoff, streams and draining to a particular watercourse or body of water).

Conversely, after 21 months of residence and research in El Huizache, the findings of this research have revealed that the story of this contaminated 
community represents an exceptional case of surface water contamination, considering that contamination of surface water typically occurs in humidtropical contexts, where rivers and lakes abound, and not in desert, semi-arid places as El Huizache, where the most common water supply - when available tends to be ground water.

The results of the research suggest as well that any analysis about toxic waste and water contamination requires a precise (governmental, scientific, and communitarian) monitoring of all water variables, watercourses, and the route of contaminants. Surface and ground water are two separate entities, so they must be regarded as such. Also, the findings provide evidence that, when it comes to a semi-arid climate, even the smallest water alteration (e.g., in precipitation level or waste disposal) can produce a devastating social change in the use, demand, and local meaning of water supplies. Finally, the particularities of the study indicate that when it comes to fair rules for siting a landfill, a semi-arid rural water pond in México should be considered a real community storage vessel and not just "a nice body of water usually smaller than a lake" [4].

\section{Ethnographic research in EI Huizache (a village under stress from climate, toxic waste dumping, and water contamination)}

Most of the data analyzed in this paper was gathered during 21 months of ethnographic research and residence in El Huizache, from August 2005 to April 2007. During the first stage of fieldwork, common events that tend to generate suspicion of water contamination from toxic waste dumping (unexplained health problems, odour, bad taste and colour of the water consumed in the community) were the main aspect of study. To gather such information, it was necessary to participate in a wide range of activities related to the use of water in daily life (drinking, cooking, cleaning, bathing, and doing laundry).

During the second stage of research -intended to identify the effects of any chemical discharge on the environment- human symptoms and reactions from consumption of contaminated water and toxic air breathing (such as skin and eyes irritations, gastrointestinal illness, nausea, dizziness, swelling of the respiratory tracks, breathing and sleeping difficulties) became the focus of attention.

Complimenting the participant observation data, a series of semi-structured interviews with two local civil authorities, and 26 community residents $(20$ men and six women) were conducted and taped. Each interview included questions about chemical contamination and residential toxic exposure (a pair of concepts proposed by Edelstein [5], Brown and Mikkelsen [6], and Settergberg and Shavelson [7]).

During that time, the experience of being in the place, living and speaking with people in El Huizache, started to expose the adverse conditions of the village, especially poor economic development, lack of potable water, low precipitation level (low rainfall, and the subsequent drought, crop failure, and 
livestock deaths), lack of job opportunities, absence of medical services, as well as desolate condition of roads, streets, and houses of the community.

Furthermore, it became clear El Huizache was the nearest village to the toxic waste dump in La Pedrera, and there was no physical obstacle - natural or manmade - between the community and the toxic site (there were only dried watercourses, small ravines, and little canyons that connected each other). Then it was found La Pedrera was the name for an arroyo located upstream, that in the rainy season carried water from the contaminated soils of the waste dump to the vulnerable floors of the community. At the end of its extension, the arroyo flowed into El Huizache, transforming the streets of the village (most of the time dry and arid, depending on the intensity of the droughts that, according to locals, might last up to two years) into watercourses running through the community and finally draining to El Huizache's water pond. Figure 1 shows a visual representation of the area.
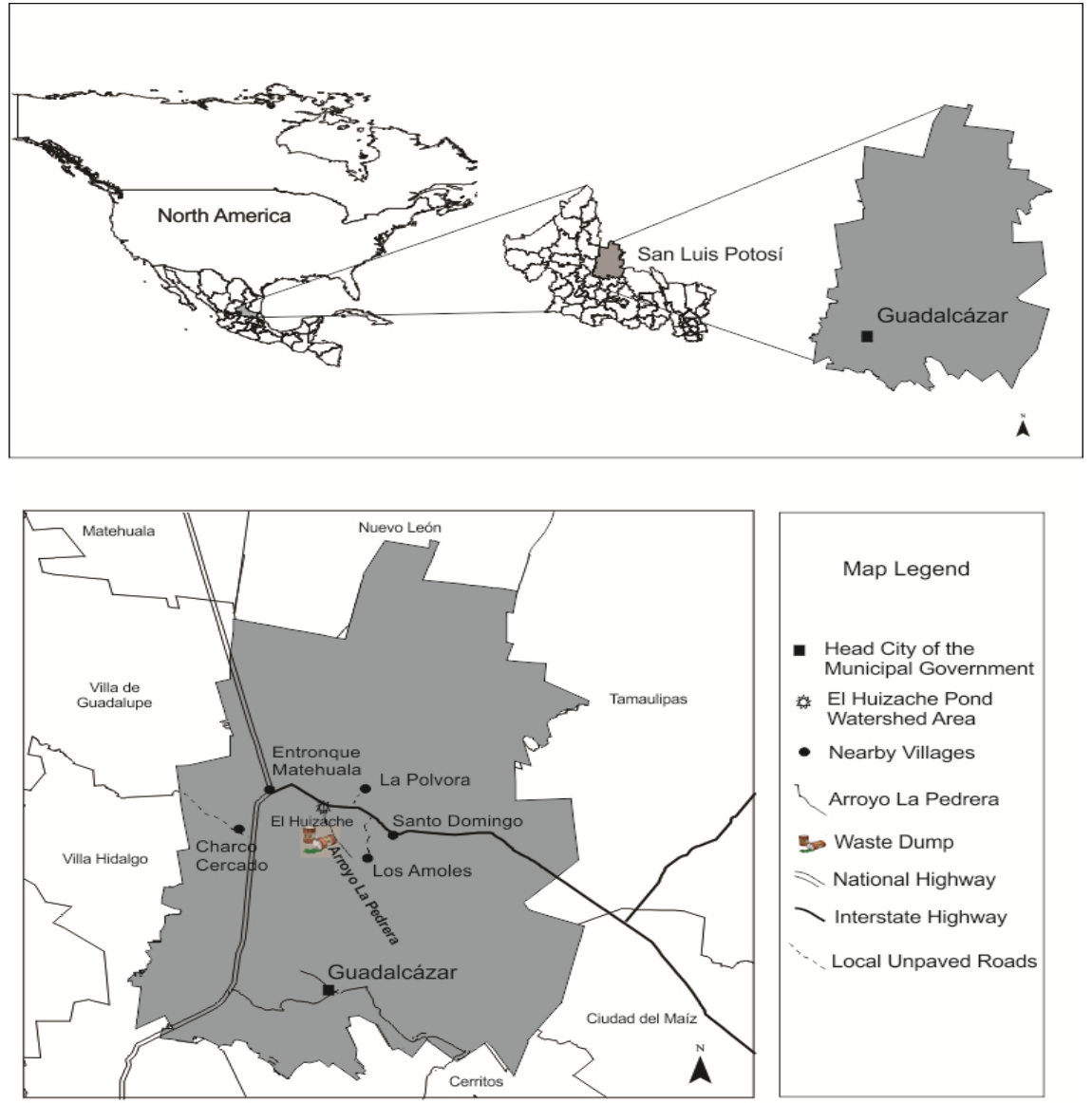

Figure 1: Location map. 
Subsequently, and contrary to one of the first assumptions of research, it was found that water scarcity was not a simple common feature El Huizache shared with most of the localities in "El Altiplano Potosino" (a semi-arid plateau for excellence). Unlike neighbouring villages as Charco Cercado, La Pólvora or Los Amoles, El Huizache did not have a ground water source, nor was benefited by the flow of a natural spring. The only water supply was the local pond, a body of water that served as dam to capture rain water, primarily intended for livestock and domestic use. In the end, the forgotten history of this contaminated community started to reveal.

\section{Disabling people: the governmental response to water contamination}

During the rainy days of May 1991, torrents of upstream rain-water surprised the inhabitants of El Huizache, carrying to their water pond the contents of several 200-liter drums and plastic bags filled with toxic waste. Months ago, Mexican company Coterin had improperly dumped over twenty thousand tons of hazardous waste in La Pedrera, "which came mainly from the metal-mechanical, chemical, pharmaceutical, agrochemical and automotive industries" [8].

After noting toxic waste reaching their water pond, some residents of El Huizache (fearful and angry about the consequences the incident might have) reported the matter to their local representatives and to the heads of the City of Guadalcazár, who then reported the case to the appropriated federal authority. In response to that complaint (while evaluating the matter, and without punishing those responsible for the incident), Mexican environmental officials tried to secure the place, giving the perpetrators federal permits to build (transform the dump into) a waste transfer area, "with the intention of remedying the mess, and hopping the restoration of the site might serve as a sample of their will to reduce the improper disposal of hazardous waste in México" [9]. However, Coterin did not get the necessary permits form local government, and in 1993 sold the site to Metalclad, an American landfill management firm [10].

That response of the federal authorities stressed the concern of the population, and rarefied the atmosphere of necessary consensus for a possible solution. Such a response, also caused a split opinion in the community (a phenomenon of partial opposition to the dump, because some of the locals saw the idea of transforming the dump as an opportunity for job creation), and led to a lengthy debate in which proponents and opponents, experts, technicians, lawyers, and other specialists form government and industry defined key issues such as security and risks to the environment and the affected population.

In the heat of the controversy, the different assessments of the situation led to the closure of the dump, and stopped all federal government strategies to remedy the problem, including that intended to transform the site into a secure landfill by Metalclad. In 1997, failing to achieve its purpose, Metalclad sued the Mexican Government for the refusal of local governments in the state of San Luis Potosí, and the municipality of Guadalcazár, under chapter 11 of the North American Free Trade Agreement (NAFTA) for 90 million dollars, and was awarded \$16.7 
million. This award was later reduced by $\$ 1.1$ million to $\$ 15.6$ million, by review in the courts of British Columbia (the jurisdiction where the NAFTA hearing was held) due to a recalculation of the applicable interest period.

When the dump was closed and the incident turned into an international conflict, the consequences to the place and to the community were forgotten. Some scholars took the opportunity to open the debate about the relations between international trade, foreign investment, and toxic waste disposal. Some recognized, first, that foreign interference in a project involving potentially dangerous substances or activities affects the degree of local opposition to the project: "It has became clear that the entry of Metalclad has worsened the emotional atmosphere around the dump, as the Coterin people sat comfortable to enjoy a show where their place had been occupied by someone much more hateful: a U. S. company" [11].

To others, the case revealed that, sometimes, the remediation plan for a hazardous waste dump can be, in itself, another threat to nearby populations: "The process of remediation offered by Metalclad came to be viewed with great suspicious, as involved the carrying of more wastes to the site, a process that increased the opponents concern, because it increased the chances to impact the environment and represented a threat to the safety of the communities near the site" [12].

Finally, some studies derived from the case suggested that "the siting of a project that involved hazardous substances or activities may erode contexts, relationships and political dynamics, as well as transform, episodically, civic consciousness, individual and group interventions, and institutional power arrangements" [13] (as some observers argue, "hazardous waste is a technological problem with economic overtones and political consequences, and the governmental mechanisms set up to tackle the issue are understandably complex and fall short of the mark" [14]).

However, neither the actors directly involved in the case, nor the case studies carried out, addressed the locals' concerns over safety and fairness, so the inhabitants of El Huizache suddenly found themselves in a complex institutional context made up of the various local, state, and federal agencies having jurisdiction over their contaminating incident.

Being in the community, it was possibly to ascertain that the multiple risk assessments people in El Huizache were exposed to, caused different risk perceptions about the pollution of the water pond, prompting a dramatic change in the use, perception, and social dynamics around this small local damn. As noted by Edelstein (on human responses to environmental contamination), the result of this change in circumstances for most toxic victims were their virtual entrapment in a double blind. They learned that they are neither sufficiently at risk to warrant definitive action by government nor sufficiently free of risk to return to life as usual. Effectively, toxic victims in El Huizache become disabled, as suddenly they were depending on professionals to expertly handle various areas of life formerly governed by their own naive wisdom [15]. 


\section{What makes the desert beautiful? Local, semi-arid water pond issues for the fair siting of a landfill}

Based on Edelstein's reasoning about the meaning of any disaster being most clearly indicated by what has been involuntarily lost or changed for the worst from the ordeal, the approach for field study of toxic exposure was grounded in a comparison of victims' lives before and after the water pond pollution incident, the first serving as a baseline for analyzing the second. "It is by understanding how normal life may have been affected by contamination and related events that one can make tangible these consequences" [16].

After learning about the contamination of the water pond, and about the disablement of people in El Huizache, the research efforts focused on the pond dynamics (touring it in detail), and on a series of in-depth interviews to reconstruct the pre-contamination baseline, subsequent changes due to contamination, and their meaning. Only 26 interviews were taped since Edelstein's victim-centred approach recommends focusing on the story of those most affected for the incident, simply because it best represents those most impacted (in contrast, randomized sample studies may confound impacts by mixing those who believe in the contamination with those not viewing themselves as affected or harmed. Such data is useful for a blended assay of the overall community or to identify percentages of believers versus nonbelievers in the population, but may obscure victims and how they have been affected, minimizing the effects. The perceived victims may be a small percentage of the overall community and thus easily underrepresented in a randomized sample and their impacts washed out).

To achieve a better understanding of the contamination incident, social impacts around the pond were label as lifescape disruptions and categorized in issues as water dinking, property value, economic dynamic and social activities. In the meantime, it was ascertain that before the contamination event, the water pond worked as a local gravity centre, since the village has a geographical arrangement that resembles a pendulum prostrated and operated on a horizontal surface. The pond was the fixed point that supported the pendulum and the life of the town swung and ranged tied to the fixed point of the pendulum. It could said that in El Huizache all the roads led to the pond (the lines of its roads, pretended to be streets, indicated so). After the contamination incident, a displacement of that centre was occurring, bringing to the community a series of abrupt and unexpected changes.

In the drinking water regard, the findings revealed the water supply in the pond could last for over half a year, and that the uses locals gave to pond water ranged from bathing, washing clothes, livestock, to even cooking. However, it was heard and observed that after the pollution incident, only when full, most of the villagers drank water from the pond. But as the water level dropped, only the elderly dared to drink from it (the rest of the people preferred to wait for the council of Guadalcazár to send them potable water pipes; when that did not happened, people had to buy bottled water in one of the three small grocery 
stores that are in the village. As one resident recalled "Now we are playing the rich").

About value to rural property, in addition to the pond, there were in the village some other water reservoirs that did not store water as efficiently as the pond. In this regard, people argued that the main water supply was the pond, and it was a shame its water was contaminated. As a couple pointed out "We used that water for everything, for shower, livestock, swimming, even dinking; but when they brought those drums to La Pedrera, to the dump, they left them outside, in the sun, and they heated, and when the covers blew, then came the rain, and that was a mess, because the rain carried all the plastic bags filled with waste trough el arroyo and then messed the whole pond water. This is a step down in our lives".

The pollution of the pond also affected the economic life of the community. Before the contamination incident, all the people in the village (around 450 inhabitants, 64 ejidatarios, landowners families) needed to bring water from the pond to their houses, but not everyone could do it, not even women (as the used to do years ago), since they started to work in recent times next to men in the tomato farms near to the village. For that matter, there were "aguadores", villagers that offered the water service, using their trucks or carts to carry water from the pond to houses in 200-liter barrels, charging twelve pesos (one dollar) per barrel. A family of five used to buy two barrels of water per week, at a monthly average of 120 pesos (12 dollars). After the incident, nobody wanted to buy pond water. Even people in the vicinity started referring to El Huizache's water as "that water". The community had acquired a stigmatized identity due to the contamination incident.

In the social aspect there were also negative impacts. Socially, the pond used to be a meeting place for long talks between ejidatarios, games among children, whispers of romantic couples, and some religious celebrations. During Easter festivities, especially on Holy Saturday, in the tradition of throwing water to neighbours, the pond was the scene of a big party, attracting people of all ages and nearby places, people equipped with buckets and plastic bags that served as appropriated weapons for the occasion. In those times, water and joy overflowed, even though the pond was at its lowest level on that part of the year, and the strong wind lifted blinding dust storms. Then, after the contamination incident, the pond was socially abandoned.

On one occasion, one of the older interviewed residents of El Huizache made the following plea: "I beg you to help us with the pond. Bring some sanitation personal to order the local authorities to be more careful with our water. Ask people not to wash their trucks there; not to leave their dirty socks and used flannels. Ask them not to destroy the pond, as others have done there in the lagoon of Villa de Arista (a nearby, very contaminated, agro-industrial location). You see, not everyone has money to buy bottled water. Many people still using water from the pond. The humble, they don't have money to buy clean water. They use pond water to cook their beans. And yet, people in here are getting very dirty and neglected with the pond. I just want to be there hygiene again. I don't 
want people's crap in the pond. I don't want them to turn the pond into a dumpster".

The lamentable part of the story of this contaminated community is that during the siting dilemma nobody worried about the impacts the waste dump brought to the pond and the community, even though some of the National Water Commission (CNA) site's assessment conclusions considered the possibility of an extraordinary water run-off, not adequately controlled by the dump facilities, leaching and carrying, superficially, contaminants to the wells and water bodies located in the Matehuala-El Huizache Valley. On the same subject, the Engineering Institute of the National Autonomous University of México (UNAM) judged the main risk of contamination of bodies of water near the site laid on the possibility of water run-off coming into contact with the toxic waste deposited on the landfill. The Institute determined a good idea to design flood protection walls for surface water, and to carry out permanent surveillance activities of the water quality downstream the site.

\section{Conclusion}

Rural populations in México have always struggled with extreme poverty, as well as social and political marginalization. Dating back to the haciendas, the rural poor have struggled to own and control the land they farm, and the land they live. But when the land they farm, and the land they live, is located in a semi-arid climatic region, the struggle increases significantly. The inhabitants of a semi-arid rural land must possess considerably physiological adaptability to survive. In semi-arid regions, water shortage is a constraint requiring attention when deciding on policies for rural economic development. For these regions, water storage is a key measure in water resources development. Any force aimed against those goals upsets the rural, semi-arid, core assumptions. Thus, the exposure to toxic waste not only affected El Huizache's water supply, but also profoundly affected the ways locals live, think and feel about themselves, their governments and the world. The poor general understanding of the water-pond related issues outlined above made decision makers to neglect future negative feedback on the natural environment, although the principal outcome has generally been foreseeable. Toxic waste dumping (improper disposal) should be considered a deliberated illegal act, since treatment technology is available, and the main problem still the unwillingness to bear the cost. Toxic waste exposure is not an accident, nor a surprise. The chemical companies knew exactly what they were doing in Love Canal, N. Y.; in Woburn, Mass.; in La Pedrera, S.L.P. Orphaned landfills, midnight dumping, and unauthorized discharges from industry and municipalities leaching into ground and surface waters are not accidents, nor surprises, they are deliberated crimes committed against the population at large. Critical to the problems discussed in here is to ensure that decision makers and the general public have an adequate understanding of mankind's long-term dependence on life-supporting systems, and on the fundamental role of the water cycle in these systems. In such a way, when it comes to fair rules for siting a landfill, no one should forget that a semi-arid rural 
water pond might not just be a nice body of water smaller than a lake, but a real community vessel that serves to regulate and store the excess volume of water drained in the rainy season, in order to use the excess in time of drought, when runoff is low.

\section{References}

[1] Stoffle, R. et al., Risk Perception Mapping: Using Ethnography to Define the Locally Affected Population for a Low-Level Radioactive Waste Storage Facility in Michigan. American Anthropologist, New Series, 93(3), pp. 611-635, 1991. The concept of Risk Perception Shadow (RPS) has been suggested to describe the geo-cultural area in which a locally affected population perceives itself to be at risk from a proposed project. The initial conceptualization of an RPS was developed in 1987, during the social assessment of a proposed Superconducting Super Collider in Michigan, USA.

[2] Michael Edelstein has pointed out how the essence of this kind of relationship is depicted by Adeline Levine in her description of how Love Canal residents perceived their treatment by the New York State Department of Health. See Edelstein, M., Contaminated Communities. Coping with Residential Toxic Exposure, Second Edition, Westview Press: Boulder, Colorado, pp. 161-192, 2004.

[3] Pye, V. I. \& Patrick, R., Ground Water Contamination in the United States. Science, New Series, 221(4612), pp. 713-718, 1983

[4] Mings, L., Environmental and Social Impact Assessment for the Body Pond Watershed, Environment Tourism Consulting Ltd. St. John's Antigua $\mathrm{http}: / /$ gefantigua.org/

[5] Edelstein, M., op.cit

[6] Brown, P., \& Mikkelsen, E. J., No Safe Place. Toxic Waste, Leukaemia, and Community Action, University of California Press: Berkeley and Los Angeles, California, pp. 1-6, 1997

[7] Setterberg, F. \& Shavelson, L., Toxic Nation. The Fight to Save Our Communities from Chemical Contamination, John Wiley \& Sons: New York, N. Y., pp. 81-100, 1993

[8] Torres, B., Metalclad y Guadalcazár, El Colegio de San Luis: México, p. 6, 1999

[9] Azuela, A., Olor a Nafta. El caso Metalclad y la nueva geografía del derecho Mexicano, UNAM: México, p. 5, 2004

[10] There is evidence that the authorization to Coterin to remedy the dump was granted just because the sale of the site to Metalclad was already under negotiation. See Azuela, A., op. cit., p. 3

[11] Azuela, A., p. 34

[12] Torres, B., op. cit., p. 11

[13] Ugalde, V., Los residuos peligrosos en México. El estudio de la política pública a través del derecho, El Colegio de México: México, p. 71, 2008 
[14] Bouman, A., Hazardous Waste Management: An Emerging Policy Area within an Emerging Federalism. Publius, 15(1), pp. 131-144, 1985

[15] Edelstein, M., op. cit., pp. 161-162

[16] Edelstein, M., p. 35 